\title{
Current Reformed Smoker Within Past 15 Years
}

National Cancer Institute

\section{Source}

National Cancer Institute. Current Reformed Smoker Within Past 15 Years. NCI

Thesaurus. Code C156829.

An individual who stopped smoking within the past 15 years. 